\title{
CLINICAL AND AUTOANTIBODY PROFILES IN MALES AND FEMALES PATIENTS WITH SYSTEMIC LUPUS ERYTHEMATOSUS: A RESTROSPECTIVE STUDY IN 603 BRAZILIAN PATIENTS
}

Kamilla de Bessa Jorge ${ }^{1, \star}$, Laís Zanlorenzi ${ }^{1}$, Anauá Fernanda dos Santos Cavalcante ${ }^{1}$, Natália de Oliveira ${ }^{1}$, Nícolas Silva ${ }^{1}$, Renato Nisihara ${ }^{1}$, Thiago Alberto dos Santos ${ }^{1}$, Thelma Larocca Skare ${ }^{1}$

1.Faculdade Evangélica Mackenzie, Curitiba (PR), Brazil.

${ }^{*}$ Corresponding author: kamillabessajorge@gmail.com

\section{BACKGROUND}

Gender and ethnic background may influence the clinical and autoantibody profiles in systemic lupus erythematosus (SLE). The objective of this study was to compare the clinical and autoantibody profiles of SLE patients in a sample of Brazilian patients.

\section{MATERIALS AND METHODS}

Retrospective study of 603 patients (48 males and 555 females) from a single rheumatology center. Collected clinical data included: clinical findings according to SLICC classification criteria, the presence of antiphospholipid antibody syndrome and autoantibody profile: anti-dsDNA, anti-Ro, anti-La, anti-Sm, anti-RNP, rheumatoid factor, aCL (anticardiolipin) IgG, aCL IgM, lupus anticoagulant and direct anti-globulin test.

\section{RESULTS}

It was found that women had higher age at disease onset $(p=0.02)$, higher oral ulcers frequency $(p=0.001)$ and alopecia $(p<0.0001$ ). The prevalence of glomerulonephritis (odds ratio, $\mathrm{OR}=6.5$; confidence interval, $95 \% \mathrm{Cl}=3.0-13.7$ ) and anti-dsDNA $(\mathrm{OR}=2.59 ; 95 \% \mathrm{Cl}=1.38-4.85)$ was higher in men. No differences were found in the classes of glomerulonephritis $(\mathrm{p}=0.46)$.

\section{CONCLUSION}

In this group of patients, more renal involvement and less oral ulcers and alopecia were observed in men. 